\title{
REVISITING DISCOUNTED CASH FLOWS MODEL AS A CAPITAL BUDGETING DECISION TOOL
}

\author{
DOI: 10.17261/Pressacademia.2020.1349 \\ PAP- V.12-2020(13)-p.60-63
}

\section{Suat Teker}

Isik University, Department of Economics, Istanbul, Turkey. suat.teker@isikun.edu.tr, ORCID: 0000-0002-7981-3121

To cite this document

Teker, S., (2020). Revisiting discounted cash flows model as a capital budgeting decision tool. PressAcademia Procedia (PAP), V.12, p.60-63. Permanent link to this document: http://doi.org/10.17261/Pressacademia.2020.1349

Copyright: Published by PressAcademia and limited licensed re-use rights only.

\begin{abstract}
Purpose- In this study, the classical discounted cash flows (DCDF) model is revisited and the input factors of the model are analysed in details. Methodology- A model analysis approach is used in this research. The fundamental assumptions and the input factors (cash flows, time period, risk, discount rate, etc.) of DCF model are questioned.

Findings- NPV and IRR are two methods using discounted cash flows and oftenly applied for capital budgeting decisions. The assumptions used in the DCF analysis are very strong and not fitting well in the reality of practical life. Economic life of the project may be much longer or shorter than projected in the analysis. The computation of discount rate bases on subjective interpretations (weights of capital components, cost of debt, opportunity cost of equity). Estimation of cash flows is the most critical input of the analysis but generally the least weighted factor (CF or FCF, inclusion of only relevant cash flows, depreciation and interest expenses, installments, credit sales and purchases, etc.). Risk adjustment can be made either on the discount rate or expected cash flows. Moreover, the analysis of international capital investments makes the issue more complicated. Also, the inclusion of real options adds an economic value to the analysis.

Conclusion- DCF is not straight forward a capital budgeting model anyone can easily use. The application of DCF requires expertise and a picky view on details. Nevertheless, the acceptance of capital investments utilizing DCF method can not be independent of overall company strategic goals.
\end{abstract}

Keywords: Discounted cash flows, discount rate, capital budgeting decisions, expected cash flows. JEL Codes: G20, G30, G31

\section{INTRODUCTION}

Capital budgeting is a process that managers use to make decisions about whether long-term investments or capital expenditures are worth pursuing by their organizations. This process includes planning, analyzing, selecting, implementing, managing and auditing capital investments. Capital budgeting decisions involve long-term investments. They generally require large amount of initial investments and referred as capital investments. These investments are expected to generate significant cash flows for a number of future years, hold a critical part of the long term strategic planning and directly affect the sustainability of the firm.

A company strategy is the formulation and implementation of a company's key decisions. A well-designed company strategy should include a statement of the company's goals, criteria to decide which activities a company should do and should not do, a view on how the company should be organized internally, how it should deal with the external environment and contain an explanation for why the goals will be achieved by adhering to the strategy. Hence, capital budgeting decisions cover a large part of the company strategy.

In theory, capital projects should be analyzed in terms of shareholder wealth maximization. Based on this assumption, managers should undertake all investment projects with a positive net present value (NPV). By so doing, managers should enhance firm market value and consequently increase owners' wealth. In practice, managers may not necessarily accept a project just because it appears financially attractive. Achieving the financial objective of shareholder wealth maximization requires developing a business strategy. Successful capital investments affect the achievement of company's strategic objectives.

After defining the importance of capital budgeting decisions and tying to the company's strategic objectives, the following parts of the paper are organized as follows. The next section sets the assumptions and input factors of discounted cash flows (DCF) model. The following part revisits and questions each of the critical factor used in the application of DCF model. The final section concludes the findings.

\section{DISCOUNTED CASH FLOWS (DCF) METHOD}

The typical capital budgeting method (directly or indirectly) involves three steps; estimating cash flows generated by the project, finding an adequate discount rate for each cash flow, and estimating the initial cost of the investment (including opportunity costs). Discounted cash flows (DCF) method discounts all expected cash flows today and in the future at a given rate. Net Present Value (NPV) and Internal Rate of 
Returns (IRR) are two applications of DCF model. IRR is a special case of NPV. IRR is the actual percentage return generated by a project. To determine whether the project's IRR is sufficient to justify its initial costs, the project's return needs a benchmark return (hurdle rate or cutoff rate) for comparison.

Net Present Value (NPV) model may be shown as below;

$N P V=-I_{0}+\sum\left(C F_{N} /[1+k)^{t}\right)$

Input factors of a NPV computations are economic life of the project (N), initial investment (I0), expected future cash flows (CF), discount rate $(k)$, project risk (business risk, project risk, $\sigma_{\text {project }}, \beta_{\text {project }}$ ), and real options if available.

The assumptions of the model may be stated such that capital markets are perfectly efficient, no frictions in financial markets, no transaction costs, no information asymmetry, all player are rational, no differences in taxes (among financial instruments and countries) and law of one price is hold in everywhere. These assumptions used in the DCF analysis are very strong and not fitting well in the reality of practical life.

\subsection{Economic Life}

A general assumption is that all initial investments are done, completed and ready to use for operations in a single day (today at $\mathrm{t}=0$ ). Besides, it is assumed that the project's economics life is known and certain disregarding the changes in technology, competitors, trade-production restrictions, tax laws, tax rates, supply of raw materials, manufacturing parts, workers and managers. On the other hand, in the large capital investment projects the initial investment period may easily take a couple of years to put parts of operation together. The problems in licensing, construction, receiving parts, machinery, supplies, financing and labor may easily extend the initial investment period. Meanwhile the capital investment projects has been employed, the economic life of the project may be extended because of modifications in production facilities and innovations in products and production processes. On the other hand, it may be limited by changes in business environment, e.g. technology, taxes, competitors.

\subsection{Initial Investment}

The initial investment covers the acquisition of new assets, additional need for net working capital, acquisition of land and constructing a building. The costs of acquisition of new assets include invoice price, delivery, insurance for delivery, installation-testing-calibration, materials used for testing and training of workers. Additional need for net working capital (NWC) is defined as the difference in between current assets and current liabilities. With the employment of the new project, increases or decreases in account receivables/payables and inventories may be needed. If the capital investment requires replacing old assets with new ones, the differences in net cost in total acquisition cost of new and total disposal cost/revenue or old must be considerd. If a land needs to be acquired, not only the purchasing price of land but the cost of grading (property appraisal, negotiate purchase contracts, lawyer fees, commissions, licensing and taxes, etc) and improving (engineering services, traffic arrangements, driveways, fences and etc) the property must also be considered. For constructing a building for the project, the costs for architectural and engineering fees, bids form contractors, evaluation of bids and construction, and taxes must ne included in the initial investment computations.

\subsection{Expected Future Cash Flows}

The estimation of future cash flows must consider the inclusion of all relevant cash inflows and outflows, namely; positive of negative externalities, opportunity costs/revenues, all initial investments, change in net fixed assets, change in net working capital, recovery of net working capital and liquidation of assets at terminal date, collection on revenues, payments for expenses, tax advantages in initial investments earned carried on future years. It must also exclude all irrelevant cash inflows and outflows, namely; sunk costs, interest expenses, noncash revenues and expenses. Moreover, the estimation of cash flows must consider the affect of inflation and adjust selling prices (aware of price elasticity of demand), time value of credit sales and credit purchases and installments, change in tax shield on depreciation expenses, change in COGS, interest expenses on debt, loss carry forward, reinvestment of excess cash, salvage value at the terminal date, tax advantages in initial investments earned carried on future years.

\subsection{Discount Rate}

The cost of capital has two common sources; debt and equity. Cost of capital is simply calculated by the weighted average cost of each capital components (WACC)

$W A C C=w_{d} k_{d}(1-T)+w_{c} k_{s}$

Where $w$ is the weight of each capital component, $k_{d}$ is the marginal cost of debt and $k_{s}$ is the opportunity cost of equity capital.

WACC is forward looking rate of return considering financing mix. The estimation of weights is based on capital structure of the firm. A problem arises at this point questioning what values taken into account computing the weights of capital components. The book values or the market values of accounts on the balance sheet need to be considered. More, the existing capital structure or the targeted capital structure after the planned investment takes place and is recorded among the assets and liabilities on the balance sheet of the firm.

The cost of debt is the required rate of return that debt holders require on the firm's debt instruments. The average cost of outstanding debt or the cost of most recent debt or the cost of incoming debt should be used the cost of firm's debt. Moreover, the cost of debt is related to 
short term debt or long term debt, or the debt is planned to obtain through bank loans, commercial paper issues or bond issues, or pure interest cost or gross cost of borrowing including transactions costs and commissions need to be considered.

The cost of equity is the required rate of return on the firms' stockholders. The equity funds may come from existing internal sources ( $\left.k_{s}\right)$ or from issues of new common stocks for cash $\left(k_{e}\right)$. In the estimation of opportunity cost of equity three approaches are commonly used, namely; Gordon Model, Capital Assest Pricing Model (CAPM) or cost of debt plus risk premium model.

The cost of equity by Gordon Model is stated as below;

$k_{s}=\left(D_{1} / P_{0}\right)+g \quad$ or $\quad k_{e}=\left(D_{1} /\left[P_{0}-F\right]\right)+g$

Where $\mathrm{k}$ is the cost of equity, $\mathrm{D}_{1}$ is expected cash dividend per share at time $1, \mathrm{P}_{\mathrm{o}}$ is the current publicly traded stock price, $\mathrm{F}$ is the floatation cosy for new stock issues and $\mathrm{g}$ is the constant growth rate of cash dividends for infinity. Gordon model is based on the expected future cash dividend payments which can only be estimated by the estimation of constant g. However, companies may not have a perceivable dividend policy or pay no dividends at all, then it is higly disruptive to estimate a constant g even if it is not possible. Po represents the current stock price but it is not easy to define what price is the most related one, e.g. closing price of the last trading day, average price of last week/month/months/year/years, trading volume weighed price or mid-day price.

The cost of equity by Capital Asset Pricing Model (CAPM) is stated as below;

$k_{\mathrm{s}}=\mathrm{k}_{\mathrm{RF}}+\left(\mathrm{k}_{\mathrm{M}}-\mathrm{k}_{\mathrm{RF}}\right)+\beta_{\text {Project }}$

$\mathrm{k}_{\mathrm{RF}}$ is the risk free rate and approximated by Treasury Securities (1-year, 5-year, 10-year or 20-year maturity). It may be suggested to use the same maturity of Treasury Securities with the life of project. $\mathrm{k}_{\mathrm{M}}$ is the expected market return and approximated by a market index (historical returns on the index or future expected returns $\mathrm{k}_{M}-\mathrm{k}_{\mathrm{RF}}$ is the market risk premium representing the additional return is required to invest in a riskier investment. CAPM implies only market risk of project ( $\beta_{\text {Project }}$ ) explains the risk-return relation. On the other hand, Baker \& Powel (2005) argues that firm size and book-to-market ratio also affect the risk of a project. A firm's stock beta can be observed in the market if the firm is publicly traded but a project's beta can not. Then, the historical returns of a similar project may be used applying pure play method and approximating for a similar firm's beta. This firm must be publicly traded and in the same line business. Pure play firm may have a different debt structure and therefore a different level of risk. If the pure play firm includes any debt in its financing structure, the beta needs to be adjusted (unleveraged) to reflect the business risk only.

CAPM has weaknesses. CAMP assumes markets are efficient, betas are stable over time, betas can be estimated forward looking, a market portfolio exists and is representd by stock indices and its expected return is measurable. Moreover, beta measures only systematic risk and is valid for well diversified portfolios. The unsystematic risk measured by standard deviation (total risk or individual firm risk) is disregarded by CAPM.

The cost of equity by cost of debt plus risk premium is stated as below;

$\mathrm{k}_{\mathrm{s}}=\mathrm{k}_{\mathrm{d}}+$ Risk Premium

The risk premium in this approach is a subjective value determined by analysists as a reasonale and acceptable risk premium on the current or marginal cost of debt of a particular firm. The risk premium in this approach is completely different from the market risk premium in CAPM. The market risk premium is valid for all risky assets in the market while the risk premium in this approach is specific to a firm.

\subsection{Project Risk}

Project risk needs to be included in the analysis by an adjustment either in the discount rate or in the cash flows estimation. If a risk adjustment on expected cash flows is desired, a scenario analysis on cash flows for each the future years may be applied. As go further, the probability distribution of the scanarios get wider showing greater riskiness of cash flows in the future. Alternatively, by appliying simulations consider the sector and the project, certainity equivalent factors are computed. The certainity equivalent factors show the riskiness of each future cash flows by assigning a greater reduction rate on each cash flows as years go further. When adjusting the discount rate for risk (Risk Adjusted Discount Rate - RADR), a risk adjustment on WACC is usually made by adding/substracting a subjective percentage (+/- $3 \%$ for example). The next step is the risk classficiations of capital investments. The risk groups may be classified as the replacement projects (low risk group), expansion projects (average risk group) and R\&D projects (high risk group). Alternatively, the expected return and risk of each individual project is calculated and then coefficient of variation $\left(\mathrm{CV}_{\text {Project }}=\sigma / \mathrm{k}\right)$ of each project is computed to determine risk level of the project. Also, sensitivity and scenario analysis may be used to classify projects into risk groups. CAPM, on the other hand, can be used to get the risk adjusted discount rate directly by adjusting the beta for a particular project $\left[k=k_{R F}+\left(k_{M}-k_{R F}\right) \beta_{\text {project }}\right]$. Another way for inclusion of risk in discount rate is to use risk free rate and add subjective a risk premium for the business risk ( $R P_{\text {business }}$ ) and add a subjective risk premium for specific risk of the project $\left(\mathrm{RP}_{\text {project }}\right)\left[\mathrm{RADR}=\mathrm{k}_{\mathrm{RF}}+\mathrm{R}_{\text {business }}+\mathrm{R}_{\text {project }}\right]$

\subsection{International Investments}

International capital investments projects oftenly involve with dealing a number of currencies, inflation rates, interest rates on various currencies, exchange rate fluctuations, political risks, foreign exchange restrictions, foreign financing restrictions, hurdle rates for parent company and subsidiary, different tax systems and tax rates, different accounting standards (definition of revenues \& expenses, treatment of leases, valuation of loans and financial securities, changes in values of certain assets and liabilities, etc.) 


\subsection{Real Options}

Myers (1977) introduced real options for capital investments. Real options help managers gain a greater flexibility to abandon, delay or expand a project through the life time of the project. Hence, losses can be reduced and gains can be increased. Real options increase the quality and validity of the analysis since there exist uncertainties about future cash flows and timing of project initiation. Besides, irreversibility of capital investments makes real options more valuable. Types of real options may be listed as option to defer, time to build, option to abondan, option to alter operating scale, option to switch, option to upscale and multiple interacting real options (rainbow options).

\section{CONCLUSIONS}

NPV and IRR are two methods using discounted cash flows and oftenly applied for capital budgeting decisions. The assumptions used in the DCF analysis are very strong and not fitting well in the reality of practical life. Economic life of the project may be much longer or shorter than projected in the analysis. Initial investment can not happen in a single day. It may cover a long period of time (a couple of years). Some costs incurred in the initial investment period may be overlooked and not included in the analysis. The computation of discount rate bases on subjective interpretations (weights of capital components, cost of debt, opportunity cost of equity). Estimation of cash flows is the most critical input of the analysis but generally the least weighted factor (CF or FCF, inclusion of only relevant cash flows, depreciation and interest expenses, installments, credit sales and purchases, etc.) Risk adjustment can be made either on the discount rate or expected cash flows. Moreover, the analysis of international capital investments makes the issue more complicated. Also, the inclusion of real options adds an economic value to the analysis. Hence, DCF is not straight forward a capital budgeting model anyone can easily use. The application pf DCF requires expertise and a picky view on details. Nevertheless, the acceptance of capital investments utilizing DCF method can not be independent of overall company strategic goals.

\section{REFERENCES}

Alessii, Giuseppe, (2006). Payback Period and Internal Rate of Return in Real Option Analysis.Engineering Economist 51:3, $237-257$.

Arnold, Tom, and Timothy Crack. (2004a). Using the WACC to Value Real Options. Financial Analysts Journal 60:6, 78-82.

Arnold, Tom, and Timothy Crack. (2004b). Real Option Valuation Using NPV. Available at http://ssrn.com/abstract=644081.

Baker, H. Kent, and Gary E. Powell. (2005). Understanding Financial Management: A Practical Guide. Malden, MA: Blackwell Publishing.

Chen, Shimin. (2008). DCF Techniques and Nonfinancial Measures in Capital Budgeting: A Contingency Approach Analysis. Behavioral Research in Accounting 20:1, 13-29.

Courtois, Yves, Gene Lai, and Pamela Peterson. (2008). Cost of Capital." In Michelle R. Clayman, Martin S. Fridson, and George Troughton, eds. Corporate Finance: A Practical Approach, 127-169. Hoboken, NJ: John Wiley \& Sons.

Fernandez, Pablo. (2007). Company Valuation Methods: The Most Common Errors in Valuations Available at http://ssrn.com/abstract=274973.

Grinyer, John R., C. Donald Sinclair, and Daing Nasir Ibrahim. (1999). Management Objectivesin Capital Budgeting. Financial Practice and Education 9:2, 12-22.

IOMA. (2003). Analyzing New Products: Choice of Hurdle Rate \& Cash-Flow Assumptions Key to Decision Making. IOMA's Report on Financial Analysis, Planning \& Reporting 3:10, 4-7.

Jensen, Michael C. (2001). Value Maximization, Stakeholder Theory, and the Corporate Objective Function. Journal of Applied Corporate Finance $14: 3,8-21$

Myers, Stewart C. (1977). Determinants of Corporate Borrowing. Journal of Financial Economics. 5:2, 147-175.

Petty, J. William, and John T. Rose. (2009). Free Cash Flow, the Cash Flow Identity, and the Accounting Statement of Cash Flows. Journal of Financial Education 35:Fall, 41-55.

Pratt, Shannon, and Roger J. Grabowski. (2008). Cost of Capital: Applications and Examples, $3^{\text {rd }}$ ed. Hoboken, NJ: JohnWiley \& Sons. 